\title{
GOOGLE TRANSLATE ON GRAB APPLICATION: TRANSLATION STUDY
}

\author{
Niswatin Nurul Hidayati \\ Sharia Economics Department, Faculty of Economics and Islamic Business, Institut Agama Islam Al- \\ Hikmah Tuban, Indonesia \\ (niswatinnh@gmail.com)
}

\begin{abstract}
The Google Translate service is widely used in Indonesia because it is considered very helpful, including being used by the Grab application platform, which the public has increasingly used in recent years. This research focused on the study of translation used in conversations between drivers and consumers. There were indeed many kinds of research on translation, but not many have discussed the translation used on Grab platforms. This research aimed to describe some of the translation styles used and deemed necessary for Grab and Google Translate improvement. Researchers used a qualitative approach by presenting data in the form of descriptions and analysis. Several points were found to be improved in the process of translating sentences in the grab application, including omitting the translation into the target language, word by word translation, inconsistency in translating a term, the application was unable to detect abbreviations, so it was not translated, the interrogative sentence in the source language was translated into a statement sentence in the target language. This research had many limitations so that other researchers can develop it more widely in the future.
\end{abstract}

Keywords: Google Translate; Grab Application; Translation

First Received:

(January, 22 2021)
Final Proof Received:

(March 30, 2021)

\section{INTRODUCTION}

Along with the development of technology, people's lives are made easier with the many applications that are currently developing. Call it Grab, which offers a variety of services to make it easier for you to travel by Grab Car or Grab Bike services. People can also order food without having to leave the house and the food will be delivered to their house or apartment via Grab Food. Besides, there are also Grab Delivery, Rent, Subscription, Health, Token, Hotels, Tickets, Groceries, Bills, Videos, and Gift Cards services.

There is an interesting part of this service, that when someone orders something through the Grab application, the message sent by the driver will also be translated into English. This translation pattern supported by Google Translate is interesting to study through translation research. The translation is the process of transferring from the Source Language to the Target Language. Catford (1974: 1) noted that translation is an operation performed on languages: a process of substituting a text in one language for a text in another. This translation process is not an easy thing, because of the differences in several things between Indonesian and English, for example, the existence of vocabulary that is difficult to find an equivalent in English, as well as cultural differences between the 
two that can affect the use of these words. This is in line with what Hoed (2006) said that the things that often become obstacles in the translation are language customs (usage) and language style, which are part of the culture.

Language is essential for humans because it is used as a tool for communication and interaction. This is like what Catford said that language is a type of patterned human behavior. It is a way, perhaps the most important way, in which human beings interact in a social situation. The language used can be in the form of spoken or written language which is described by Catford (1974) as follows:

"The performer's activity most commonly takes the form of either vocal movements which generate sound waves, or hand movements which leave a visible trace. The first type of activity is a manifestation of languages in the spoken medium-the performer is a speaker, and his addressee(s) is/are a hearer or hearers. The second type is a manifestation of language in the written mediumthe performer is a writer, and his addressee(s) is/are a reader/readers."

In this short article, the author tried to describe several cases found in the translation of Indonesian sentences into English in the Grab application. It is well known that written language and spoken language do have different patterns, including in the use of the type or style of translation to be used. In the Grab application, there are usually two types of messages sent to users of the Grab application, it was automatic messages sent by applications with a tendency to use formal conversational language, and messages sent by the driver himself to his customers, either to ask for a specific address or if there are additional orders that the customer wants to order. The language that drivers often use is more casual or informal, of course, with a polite tone to the customer.

The author found that the automatic messages that applications usually send to customers use formal language and with a translated form that is under the rules of proper English usage. For example, Your driver has arrived and will wait for 10 minutes at the pickup location (this is an automatically generated message). However, in contrast to that, the translated form of speech sent by the driver is sometimes not following English grammar rules. One example that the writer found was in the sentence Kak nanti bayar uang pas ya, which translates to Sis, I'll pay money later (Translated by Google). In the example of the translation, it can be seen that there is a missing part of the Source Language which we cannot find in the Target Language.

The purpose of this research was to describe how the translation of conversations found in the Grab application. This research was interesting because even though there is quite a lot of research on the theme of translation, however, the author has not found any writings discussing translation analysis found on platforms like Grab which are currently increasingly being used. So, the results of this study can be a contribution to science in general, as well as a trigger for improvements to the systems owned by the Grab Application and Google Translate to be even better at translating certain contexts in the conversation. 
There were some researches had been conducted related to the translation analysis, such as (Khair, Suwarno, \& Arono, 2018) entitled Translation Analysis of Student's Work (Study of Poetry Translation). In this research, the findings mentioned that the appropriate techniques were applied at $69.3 \%$. Meanwhile, inappropriate techniques were at $30.7 \%$. The conclusion of this study was that students used the most at compensation and the lowest was a description. The students mostly successful in applying appropriate techniques at delivering messages, but were flub in recreating the poetical aspect in Target Language. Besides, there was also research conducted by Jumiaty (2019) entitled $A n$ Analysis of The Translation Products From English Text Into the Indonesian Language. The result showed that the students' error types in translating English text into Indonesian were $81.6 \%$ generated translation was a literal translation and was 11 out of 60 students, or about $18.4 \%$ used the general translation from mistranslation or lexical meaning. And also it was found out that the students' error in lexical meaning. And there were $43 \%$ which has translated in general translation errors. This analysis was very useful for the teacher and students. It helped the students to know their weaknesses and difficulties in translating English text into Indonesian. It can be concluded that the students are directed to learn more and practice translating English text into the Indonesian language.

Another research was conducted by Kusumayanthi \& Fitria, (2020) entitled An Analysis of Translation Method Used by College Students in Translating An Article. This research concluded that (1) the students use Literal translation as the method in translating a descriptive text as the most used translation method is Literal Translation that reached $69.4 \%$ as 125 sentences are indicated as the Literal Translation Method out of 180 sentences of total. (2) The challenges for students that face in translating a descriptive text goes to the lack of vocabulary. From the three previous pieces of research, it had not been found translation analysis on Grab Application. So, this research could enhance the enrichment of the translation study. Thus this study focuses on the study of translation used in conversations between drivers and consumers.

\section{LITERATURE REVIEW}

Catford (1974) in his book entitled A Linguistic Theory of Translation states that the definition of translation is the replacement of textual material in one language (SL) by equivalent textual material in another language (TL). The translation is not an easy thing because it needs to recreate the meaning in the target language with a natural equivalent. This is as mentioned by Nida and Taber (Nida \& Taber, 2003) that translation is recreating the meaning in the target language of the natural equivalent that is closest to the message in the source language, first in meaning and second in style. Concerning this equivalence, Baker (as quoted by Haq, 2017) states that the concept of equivalence includes equivalence at the word level, above-word equivalence, grammatical equivalence, text equivalent, and pragmatic equivalence. Larson (1998) in his book Meaning Based 
Translation A Guide to Cross-Language Equivalent states that a translation can be called a good translation if it meets three criteria, including: accurate, natural, and communicative. Finlay (cited by Sudana, 2014) adds that the taste or sense of the original text must be maintained so that when the translation is read, the reader does not realize that it is the translated text.

In translating a text, Newmark (1988) proposes several types of translation strategies, including: (1) transference; (2) naturalization; (3) cultural equivalent; (4) functional equivalent; (5) descriptive equivalent; (6) synonymy; (7) shift or transposition; (8) modulation; (9) compensation; (10) componential analysis; (11) paraphrasing. In addition to the type of translation strategy, there are also strategies proposed by Moentaha and Salihen (1) literal translation; (2). substitution; (3) free translation. (4). Replacement; includes: word class replacement; replacement of sentence parts; lexical replacement; translation of the antonym; addition; removal; compression; syntactic derivation; amplication descriptive translation; explication/implication (Moentaha \& Salihen, 2008).

Catford (1974) differentiates the types of translation into 3 categories, namely the terms of extents, levels, and ranks. The terms of extent include full translation vs. in part. This difference relates to the extent (in a syntagmatic sense) of the Source Language text that is submitted to the translation process. What is meant by text here is any set of languages, spoken or written, that is being discussed. According to the circumstances, a text can be a book, a volume, a chapter, a paragraph, a sentence, a clause, and so on. It can also be a less extensive fragment with formal literary or linguistic units.

In a complete translation, the entire text is put into the translation process; Whereas every part of the Source Language text is replaced with the Target Language material. In partial translation, some parts or parts of the Source Language text are left untranslated; where the text is simply transferred and merged in the Target Language text. In literary translations, it is not uncommon for some lexical items from the Source Language to be treated in this way, either because they are considered "untranslated" or to deliberately introduce "local color" into the Target Language text. The difference between full and partial translation is almost non-existent (linguistically). However, since it is important to use a partially different term in a semi-technical, syntagmatic sense, it keeps the term restricted for use in a technical linguistic sense (Catford, 1974).

The total translation in question is what is most often referred to as "translation"; that is, a translation in which all levels of the Source Language text are replaced with the Target Language material. The translation "total" is a misleading term, because, although total replacement is involved, it is not replaced by an equivalent at all levels.

In the "total" translation, the grammar and lexical of the Source Language are replaced by equivalent Target Language grammar and lexis. This substitution requires replacing phonology/graphology from the Source Language with phonology/graphology 
from the Target Language, but these are not usually replaced by the Target Language equivalent, therefore no translation, at that level. The total translation is best defined as the replacement of SL grammar and axis by equivalent TL grammar and lexis with consequential replacement of SL phonology/ graphology by (non-equivalent) TL phonology/graphology (1974).

PACTE (Proceso de Aprendizaje en la Competencia Traductora ya Evaluacion) states that the translation competency model is divided into 6 sub-competencies, namely communicative competence, extra-linguistic competence, transfer competence, instrumental and professional competence, psychophysiological competence, and strategic competence (Beeby, 2004).

1. Communicative Competence in two languages can be defined broadly as the underlying system of knowledge and skills required for linguistic communication. Canale distinguishes between linguistic, discourse, and socio-linguistic components. Of course for translators, this competency must be separated into understanding in the Source Language and production in the Target Language.

2. Extra-linguistic Competence consists of general knowledge and special knowledge that can be activated according to the needs of each translation situation. These subcomponents can include explicit or implicit knowledge about translation, bicultural, encyclopedic, and subject knowledge.

3. Instrumental-Professional Competence consists of knowledge and skills related to trade and professional tools. The subcomponents may be very diverse: knowledge and use of all kinds of documentation sources and new technologies, knowledge of the job market, and how to behave as a professional translator, especially concerning professional ethics.

4. Psycho-physiological Competence can be defined as the ability to use all types of psychomotor, cognitive, and attitude resources. The most important of these are perhaps psychomotor skills for reading and writing; cognitive skills (eg memory, attention span, creativity, and logical reasoning); psychological attitudes (eg intellectual curiosity, persistence, thoroughness, critical spirit, and self-confidence).

5. Transfer Competence is the main competence that integrates all other things. This is the ability to complete the transfer process from the Source Text (Source Language) to the Target Language, namely to understand the Source Language and express it again in the Target Language, taking into account the translation function and the characteristics of the receptors. These sub-components include (1) comprehension competence (the ability to analyze, synthesize, and activate extra-linguistic knowledge to grasp the meaning of the text), (2) the ability to "deverbalize" and maintain the Source Language and Target Language in separate compartments (i.e. to control interference.), (3) competence of re-expression (textual organization, creativity in the 
target language), (4) competence in implementing translation projects (choice of the most adequate method).

Strategic Competence includes all individual procedures, consciously and unconsciously, verbal and non-verbal, used to solve problems found during the translation process. The problem-solving process can be described as a series of recursive, complex actions or actions that lead from the initial state to the goal. There are several stages in this process, the first is to identify the problem. Examples of strategies include distinguishing between primary and secondary ideas, building conceptual relationships, seeking information, paraphrasing, re-translating, translating aloud, and establishing a sequence of documentation.

\section{METHOD}

This research was qualitative descriptive research. The steps used by researchers in this study were 1) Collecting conversation data between consumers and drivers 2) Making transcription of the conversation data 3) Categorizing the types of translations that exist between consumers and drivers 4) Analyzing the data found 5) Drawing a conclusion. The data used in this research were the transcription of a conversation between Grab driver and customers in the duration of January up to December 2019. From the range of time, there were 29 sentences found as the data. The data analysis steps used in this study are the Analysis Interactive Model from Miles and Huberman (2014) which divides the steps in data analysis activities into several parts, including data condensation, data display, and drawing conclusions.

In the stage of data collection, the author collected the data from the Grab Application used in the range of January up to December 2019. From the data collection, there are two kinds of data found, the translated text from the application and Grab driver. In this case, the author used the text delivered by the driver as the data. So, in the stage of data reduction, the author reduced the data to the Grab driver text only amounted to 29 sentences. Then, for the data display, the author had displayed the data on the table in the following part. Besides, the author described what had been found from the data and made an analysis. Then, the author concluded the description.

\section{RESULTS AND DISCUSSION}

\section{Results}

The author took data from the use of the Grab application from January to May 2020 with the following findings: 
Table 1.

Data on the Grab Application

Source language (SL)

Kak nanti bayar uang pas ya

Oke alfamart ya

Macet mbak

Siap

Sudah didpn

Tak cobak nanti cari tukeran di jalan

Sy d sini

Samping rektorat

Baik

Waduh..gmana ya ini say acari tukeran gak ada kak

Disini ya

Posisinya dimna

Mbk nya pakai kerudung

Soalnya saya juga punya 50 aja

Ditunggu nggeh

Ditunggu ya mbak

Ditutup pintu masuknya

D tunggu

Mohon ditunggu ya

Pintu masuk ke hotel $\mathrm{x}$ ditutup

Posisi dimana mbak?

Alamatnya ruko2 nggeh

Gk boleh masuk ya mbak?

Totalnya berapa kak

Saya masih isi bensin ditunggu ya mbak

Owalahh

Sebentar saya masuk

Baik makasih

Sudah

Ya ini mundur

\section{Target Language (TL)}

Sis, I'll pay money later

Okay alfamart yes

It's stuck, miss

Ready

Already didpn

Don't try to find a way back

I am here

Next to the rector

Well

Oops..how do I look for this exchange there is no sis

Here yes

Where is it?

Use the veil

Because I also have 50 only

Is waiting

Wait, man

Closed the entrance

D wait

Please wait for me

The entrance to the hotel $\mathrm{x}$ is closed

Position where mbak

The address is too shabby

I can't go in

Total beerpa kak

I am still filling the gas awaited, miss

Oalahh

I'll be right in

Good...makasii

Already

Yes it's backwards 
From the data above, the authors can classify them into several groups, consisting of:

\section{Omission in translation into the target language}

The omission in this translation is found in the first data, it was Kak nanti bayar uang pas ya which was translated into Sis, I'll pay money later. The word uang pas is not translated perfectly, it only translates to money. Besides, the context of the conversation was not well-read. The expression Kak nanti bayar uang pas ya is an order or request from the Grab driver to his customers, but in the translation given, it becomes a statement. The subject who will pay is different from what the subject of the sentence should be, it was you (customer) to become I (Grab driver).

\section{Word by word translation}

Newmark (as quoted by Hidayati, 2020) mentioned that Word-for-word translation is often demonstrated as interlinear translation, with The TL immediately below the SL words. The SL word order is preserved and the words translated singly by their most common meanings, out of context. Cultural words are translated literally. The main use of word-forword translation is either to understand the mechanics of the source language or to construe a difficult text as a pre-translation process.

Some data use the word by word translation. For example, in the sentence, Oke alfamart ya which was translated into Okay alfamart yes. There was also a sentence di sini ya which was translated into here yes. Another example was also found in the sentence Waduh..gmana ya ini say acari tukeran gak ada kak which was translated into Oops..how do I look for this exchange there is no sis, specifically in the expression gak ada kak which was translated into there is no sis.

\section{Inconsistency in translating a term}

In this case what is meant is the translation of the term mbak, which was translated into miss and man. In fact, in several sentences it was found that the word mbak was missing in the target language. This was shown in the sentence Macet mbak which was translated into It's stuck, miss. It was also found in Ditunggu ya mbak which was translated into Wait, man. As for the term that omits translation lies in the sentence.

\section{The application is unable to detect the abbreviation, so it is not translated}

This case was found in Sudah didpn which was translated into already didpn. The part of sentence didpn was abbreviation of di depan in which it was often used by Indonesian people, specifically young people who often use it. The same case found in the sentence Pintu masuk ke hotel $x$ ditutup which was translated into The entrance to the hotel $x$ is closed. The word " $\mathrm{x}$ " is the abbreviation of nya often used by Indonesian people to fasten in writing sentences. Another case was Alamatnya ruko 2 nggeh which was translated into The address is too shabby. The number 2 which was written in the Source Language indicated the repetition of the word ruko which means some stores in the 
mentioned address. Due to the inability of Google Translate in identifying the things, the translation version in the Target Language was too far from the meant context, in which the word ruko which can be translated into store becomes the word shabby.

\section{An interrogative sentence that turns into a statement sentence or a command sentence}

This case was found in the sentence Gk boleh masuk ya mbak? Which was translated into I can't go in. The same thing was also found in the sentence Mbk nya pakai kerudung which was translated into use the veil. Google Translate is quite widely used in Indonesia. Indonesia is included in the top 10 countries that use it the most. This is quoted from the official Kumparan website in 2017, that according to Macduff, Engineering Director of Google Translate, many Indonesians use Google Translate to read articles or chat. Google Translate is very helpful for people who do not fully understand foreign languages, especially English, in this matter. This platform is capable of translating 103 languages, and in 2020, Google Translate will add 5 additional languages to its platform, namely Kinyarwanda (Rwanda), Odia (India), Tata, Turkmen, and Uyghur (Suara.com, 2020).

The growth of Google Translate users in Indonesia is quite high. Per year, the growth of users of this platform in Indonesia reaches more than 300 percent via mobile devices and 94 percent via the desktop web. Google also continues to improve the capabilities of its platform. Now, Neural Machine Translation (NMT) technology, already supports Indonesian to English translation or vice versa. Technology that uses artificial intelligence can provide translation results that are more accurate, natural, and easy to understand.

NMT technology is no longer looking at the word for word but will look at sentences as a whole, also uses a wider context to find the most relevant translation results, adjusted to the correct grammar in the conversation. One of the problems faced by Indonesians is the use of grammar or grammar in English, so this technology can help overcome these problems. Google is continuously improving this technology over time by collecting the latest data.

Indonesia is considered to be one of the largest and fastest-growing countries in using the translation feature from Google. It is recorded that the annual user growth (YoY) reaches $50 \%$ on Android devices. While on the desktop, the growth reached $94 \%$. Meanwhile, translation via mobile devices increased 354\% from the previous year. This is also the reason Google brings Neural Machine Translation (NMT) technology to the translation process. This technology looks at the whole sentence, not word for word anymore. Besides, NMT uses a broader context. So that the translation results are most relevant and following the spoken language with proper grammar. Macdaff, who is the Engineering Director of Google Translate, stated that the translation results from Google Translate are closer to human translation (Rahman, 2017).

One application that uses the Google Translate platform to translate the contents of conversations between drivers and consumers is Grab. From the data collected by the 
authors above, several errors were found. The data is taken from experience while using the application, both for ordering Grab Food, Grab Bike, and Grab Car. This also happened to several other users who were compiled in one of the news releases written on CNN Indonesia (eks, 2019).

However, in the previous subtitles, it was found that Google Translate was not able to fully accommodate several things, for example, related to the choice of words, terms, sentence contexts, and abbreviations often used by Indonesians. The example of translation on the Grab application can be seen in the following figures.
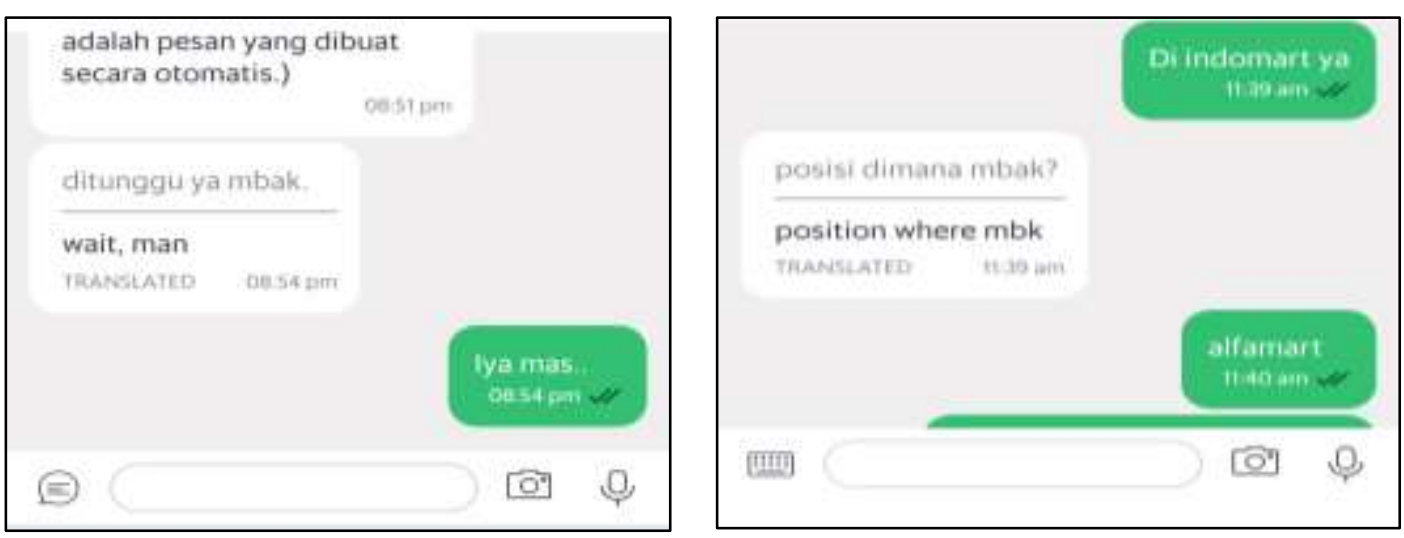

Fig. 1. Example of data found in the conversation on Grab Application
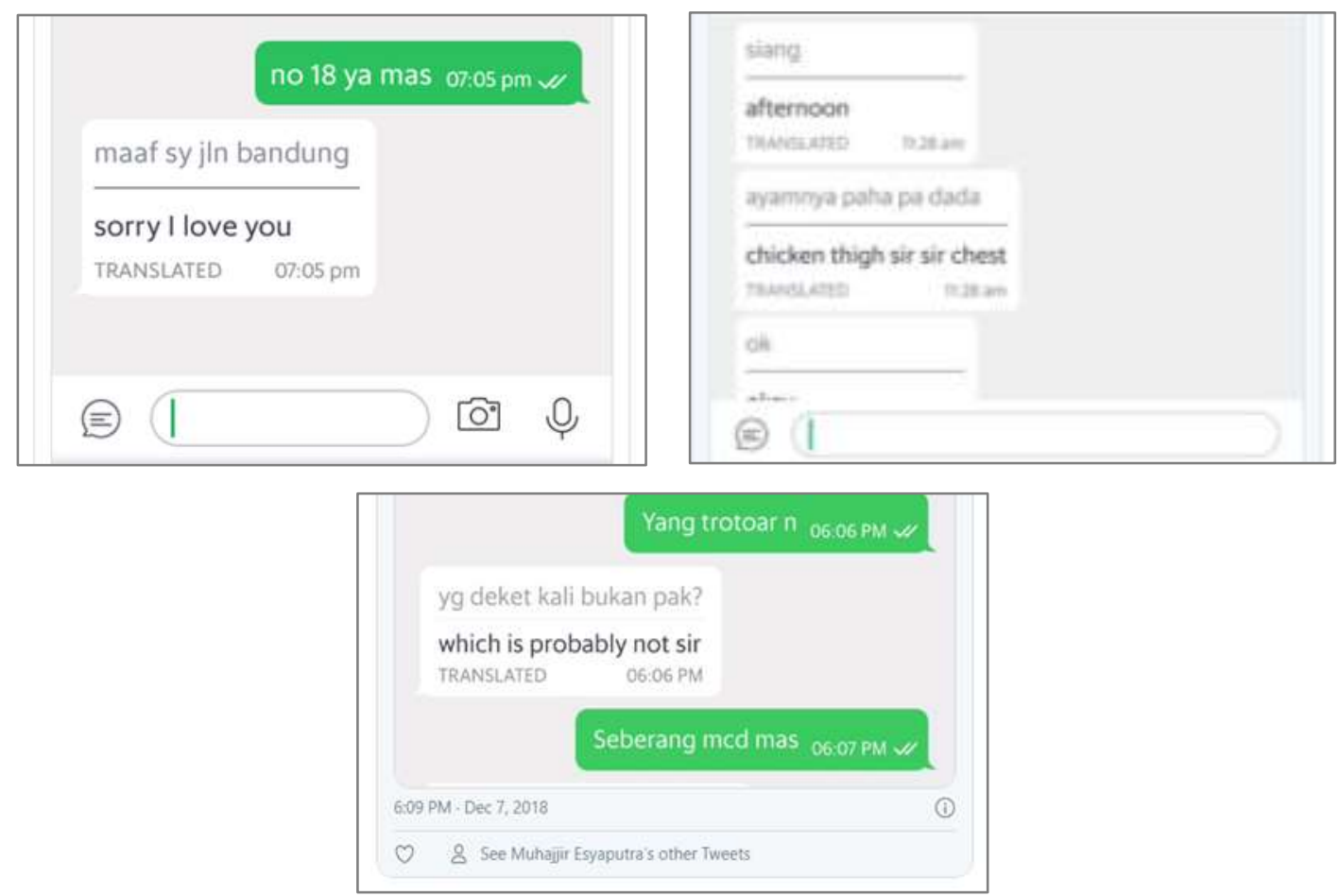

Fig. 2. Example of translation on the Grab application (quoted from the CNN Indonesia page) 
The from one of the examples above, it could be said that the translation of the term mbak, which was translated into miss and man. In fact, in several sentences, it was found that the word mbak was missing in the target language. This was shown in the sentence Macet mbak which was translated into It's stuck, miss. It was also found in Ditunggu ya mbak which was translated into Wait, man. As for the term that omits translation lies in the sentence.

\section{DISCUSSION}

Research on Google Translate has been carried out by several researchers, one of which is Purwaningsih, where he compares the results of translations carried out by Google Translate with the results of human translations. The results show that Google Translate does have positive sides and it is quite helpful for some people who need a quick translation process. However, as a machine, it cannot maximally result in accurate, acceptable, and readable translation because it does not have translation competencies which are very important in translating a text (Purwaningsih, 2016: 1-9).

Another research was conducted by Rahmannia and Triyono where both of them examined the errors found in translation using Google Translate. The results of their research showed that the translation errors that occur include four categories, it was the omission of meaning, the addition of meaning, deviation of meaning, the diction of meaning. Of the four categories, deviation of meaning is the most dominant (Rahmannia \& Triyono, 2019).

From the two previous pieces of research above, it can be seen that machine translation has certain drawbacks, despite the great benefits it provides to users for interpreting a word or sentence in a foreign language. This is because machines or systems have several competencies that are currently not owned or are limited, which are different from human translators. PACTE (Proceso de Aprendizaje en la Competencia Traductora ya Evaluacion) states that the translation competency model is divided into 6 sub-competencies, namely communicative competence, extra-linguistic competence, transfer competence, instrumental and professional competence, psychophysiological competence, and strategic competence (Beeby, 2004).

Several translations have not been conveyed properly from the Source Language into the Target Language. According to translator Peter Newmark (1981), irregularities in translation can occur when: (1) shifting sentences in translation often cause semantic oddities due to lexical translation with changes in word order; (2) there are generally words or phrases or sentences that are not translated; (3) translators use individual languages rather than social languages commonly used in society; (4) changes in viewpoints that are different from the source language; (5) the number of grammatical and lexical errors. Furthermore, Sager proposed a classification of types of deviation in translation, namely the existence of meaning reversal, omission, addition, deviation, and 
meaning modification (Haq, 2017). Although there have been quite a several researchers who have conducted research related to Google Translate, the author has not found any research that examines its use on the Grab application.

\section{CONCLUSION}

From the findings in the previous section, it can be seen that Google Translate used in the Grab application has several weaknesses in translating, for example in translating abbreviations, inaccurate choice of words to use, word by word translation, inconsistency in translating a term, and changing sentence form from the interrogative sentence to the statement sentence. Every day the Google Translate system is getting better and it is even claimed to be almost closer to a human translator, but this system still needs to be improved in a few points above. With the results of this study, the authors hope that both Google Translate and the Grab application will continue to increase these points. This research has many shortcomings so that the next writer or researcher can develop it, for example researching other applications that use the Google Translate service and being able to compare them. Research with the theme of using Google Translate in the Grab application and other applications has not been widely carried out in Indonesia, so in the future, the opportunity to develop it is wide open.

\section{REFERENCES}

Beeby, A. (2004). The Competencies Required by the Translator's Roles as a Professional. Philadelphia: John Benjamins Publishing Company.

Catford, J. C. (1974). A Linguistik Theory of Translation. New York: Oxford University Press. eks. (2019). Cuitan Kocak Netizen Soal Terjemahan "Ngaco" Grab. Retrieved March 25, 2021, from Teknologi website: https://www.cnnindonesia.com/teknologi/20190508171949-192-393136/cuitankocak-netizen-soal-terjemahan-ngaco-grab

Haq, Z. (2017). Penerjemahan Subtitle dari Bahasa Inggris ke dalam Bahasa Indonesia (Penelitian Analisis Isi pada Subtitle Film Contraband). DEIKSIS, 9(01), 100-108. doi: 10.30998/deiksis.v9i01.931

Hidayati, N. N. (2020). Rethinking The Quality of Children's Bilingual Story Books. $A L$ ASASIYYA: Journal of Basic Education, 4(1), 46-60. doi: 10.24269/ajbe.v4i1.2226

Hoed, B. H. (2006). Penerjemahan dan Kebudayaan. Jakarta: Pustaka Jaya.

Jumiaty, A. A. (2019). N Products from English Text into Indonesian Language. Klasikal: Journal of Education, Language Teaching and Science, 1(1), 48-54. doi: 10.52208/klasikal.v1i1.10

Khair, S., Suwarno, B., \& Arono, A. (2018). Translation Analysis of Student's Work (Study of Poetry Translation). JOALL (Journal of Applied Linguistics and Literature), 3(2), 119140. doi: 10.33369/joall.v3i2.6862 
Kusumayanthi, S., \& Fitria, T. (2020). An Analysis of Translation Method Used by College Students in Translating An Article. English Journal Literacy Utama, 4(1), 168-178. doi: 10.33197/ejlutama.vol4.iss1.2020.388

Larson, M. L. (1998). Meaning-based Translation. Lanham: University Press of America.

Miles, M. B., Huberman, A. M., \& Saldaña, J. (2014). Qualitative Data Analysis: A Methods Sourcebook (3rd ed.). Thousand Oaks, Califorinia: SAGE Publications, Inc.

Moentaha, \& Salihen. (2008). Bahasa dan Terjemahan. Jakarta: Kesaint Blanc.

Newmark, P. (1981). Approach to Translation. Oxford: Pergemon Press.

Newmark, P. (1988). A Textbook of Translation. Hertforshire: Prentice Hall International.

Nida, E. A., \& Taber, C. R. (2003). The Theory and Practice of Translation. Leiden: E. J. Brill.

Purwaningsih, D. (2016). Comparing Translation Produced by Google Translation Tool to Translation Produced by Translator. Journal of English Language Studies, 1(1), 1-9. doi: $10.30870 /$ jels.v1i1.678

Rahman, A. F. (2017). Indonesia Masuk 10 Negara Paling Hobi Google Translate. Retrieved March 25, 2021, from Detikinet website: https://inet.detik.com/cyberlife/d3485785/indonesia-masuk-10-negara-paling-hobi-google-translate

Rahmannia, M., \& Triyono, S. (2019). A Study of Google Translate Translations: An Error Analysis of Indonesian -to-English Texts. International Journal of Linguistics, Literature and Translation, 2(3), 290306. doi: 10.32996/ijllt.2019.2.3.22

Suara.com. (2020, February 28). Google Translate Tambah Lima Bahasa Baru. Retrieved March 25, 2021, from Suara.com website: https://www.suara.com/tekno/2020/02/28/070000/google-translate-tambahlima-bahasa-baru

Sudana, P. A. P. (2014). Analisis Penerjemahan Istilah Budaya pada Novel Negeri 5 Menara ke dalam Bahasa Inggris: Kajian Deskriptif Berorientasi Teori Newmark. Jurnal Ilmu Sosial dan Humaniora, 3(2), 11. 